AL-QANȚARA

XXXIV 1, enero-junio 2013

pp. 7-34

ISSN 0211-3589

doi: 10.3989/alqantara.2013.001

\title{
The Term Mamlük and Slave Status during the Mamluk Sultanate
}

\author{
El término mamlūk y la condición de esclavo \\ durante el sultanato mameluco
}

\author{
Koby Yosef \\ Bar Ilan University, Israel
}

Los estudiosos del sultanato mameluco generalmente sostienen que todos los mamlūks formaban parte de una élite que se sentía orgullosa de su origen esclavo incluso después de ser liberados. En este artículo se argumenta que esas afirmaciones están basadas en una interpretación errónea del término mamlūk según su uso en las fuentes mamelucas. El término mamlūk tiene un doble significado: esclavo y sirviente, y expresa frecuentemente subordinación, obediencia y servidumbre. Nunca se utiliza como expresión de orgullo de la condición de esclavo o de un origen esclavo. No hay evidencias de que los mamlu $k \mathrm{~s}$ liberados se sintieran orgullosos de su anterior condición de esclavos; por el contrario, los esclavos liberados con aspiraciones hicieron grandes esfuerzos para borrar su pasado servil pretendiendo un origen elevado o creando lazos matrimoniales con las familias más tradicionales. Los mamlüks eran considerados como «propiedades» y carecían de una identidad legal en sí mismos. Por lo general eran liberados solo tras la muerte de su amo y se veían a sí mismos como esclavos por carecer de lazos familiares con sus amos. Solo unos pocos, excepcionalmente, conseguían una liberación completa de su estatus y conseguían convertirse en miembros de una élite dirigente con lazos familiares. Parece que desde el tercer reinado de al-Nāṣir Muḥammad b. Qalāwūn, la esclavización de los mamlūks turcos que habían sido vendidos por sus familias se convirtió en una
Scholars of the Mamluk Sultanate generally maintain that the status of all the mamlüks was that of an elite, and that the mamlüks were proud of their slave origin even after manumission. It is here argued that these assertions are based on a misconception of the term mamlu $k$ as used in Mamluk sources. The term maml $\bar{u} k$ has a double meaning: slave and servant, and it frequently expresses subordination, obedience and servitude. It is never used to express pride in slave status or slave origin. There is no evidence that manumitted mam$l \bar{u} k s$ were proud of their slave status. On the contrary, manumitted slaves with aspirations made great efforts to repress their servile past by claiming an exalted origin or by creating marital ties with established families. Mam$l \bar{u} k s$ were considered property and they lacked a legal identity of their own. They were often manumitted only upon their master's death. They perceived themselves as slaves for lacking family ties. Only an outstanding few succeeded in completely freeing themselves of their slave status and become members of a ruling elite with family ties. It seems that starting from al-Nāsirir Muhammad b. Qalāwūn's third reign the enslavement of Turkish mam$l \bar{u} k s$ who had been sold by their families became more of a formality. On the other hand, non-Turkish mamlüks, who were generally Christian war captives, were subject to discrimination. They were disdained, manumitted at a later age and prevented from establi- 
formalidad. Por otro lado, los mamlūks que no eran turcos, generalmente cautivos de guerra cristianos, eran discriminados y despreciados; solo se les liberaba cuando eran ancianos y se les impedía establecer lazos matrimoniales con los Qalawuníes así como crear sus propias familias siendo jóvenes. Eran percibidos por sus contemporáneos como «más esclavos» que los turcos mamlūks.

Palabras clave: mamelucos; Sultanato mameluco; condición de esclavo; esclavitud militar; élites de esclavos. shing marital ties with the Qalawunids and creating their own families at a young age. They were perceived by their contemporaries as being "more slaves" than the Turkish mamlüks.

Key words: Mamlūks; The Mamluk Sultanate; Slave status; Military slavery; Slave elites.

Mamluk authors almost always refer to the political regime that ruled Egypt, Syria and adjacent areas for two-and-a-half centuries $(648 / 1250-923 / 1517)$ as "the state of the Turks" (dawlat alatrāk/dawlat al-turk/al-dawlah al-turkiyah). They seem to be aware of the fact that the reign of the "Turks" is divided into two periods - the rule of the Turks (dawlat al-atrāk) and that of the Circassians (dawlat al-jarākisah), and they clearly emphasize the ethnic origin or language of the ruling elite. Only rarely, and only in the Circassian period of the Sultanate (784/1382-923/1517), do they explicitly refer to the Sultanate as being ruled by slaves. Despite this fact, modern scholars almost without exception use the term "the Mamluk Sultanate" (dawlat al-ma$m \bar{a} l \bar{i} k$ ), that is, an appellation that emphasizes the elite's and rulers' slave status or slave origin. ${ }^{1}$ This appellation distorts Mamluk writers' perceptions of their ruling elite and its defining characteristic, and reflects a view propagated by David Ayalon and still held among modern scholars, that in that period the right to rule and hold key positions in the Sultanate was reserved almost exclusively for mamlüks; that the ruling elite's main characteristic was mamlük descent; that the status of all the mamlüks was that of an elite; and that the mamlukks were proud of their slave origin even after manumission. ${ }^{2}$

${ }^{1}$ For a detailed discussion, see Yosef, "Dawlat al-Atrāk or Dawlat al-Mamālìk?".

2 Ulrich Haarmann, Amalia Levanoni and D.S. Richards, among others, drew attention to the important role of non-mamlūk elements in Mamluk society, see for example Haarmann, "Joseph's Law"; Haarmann, "The Sons of Mamluks as Fief-holders"; Haarmann, "Arabic in Speech, Turkish in Lineage"; Levanoni, "Awlād al-Nās in the Mamluk Army"; Richards, "Mamlūk Amirs and Their Families". This, however, is less relevant to the matter at hand, namely, the meaning of the term mamlūk and slave status in the Mamluk Sultanate. 
Although D. S. Richards maintained that "Mamlūks entered no charmed circle, no special caste" and that it is "absurd to think that any mamlu $k$, merely by virtue of that legal status, had a real expectation of power, wealth and influence", ${ }^{3}$ and Robert Irwin argued that most mamluks cannot be regarded an elite, ${ }^{4}$ generally, scholars of the Mamluk Sultanate are still of the above-mentioned opinion. For example, Linda Northrup maintains that "having been a slave was a condition for eligibility to the highest ranks of military society", and that even after manumission "the recruit, now free, retained his mamlūk and, therefore, elite status". ${ }^{5}$ In a similar manner, Reuven Amitai holds that "even after official manumission at around the age of twenty or younger, at the ceremony known as kharj, where the trainees received a certificate of release, the soldiers still proudly regarded themselves as mamlūks, jealously guarding their status...", or that "officially free Mamluks still overtly referred to themselves as mamāli $k$, proud of their special slave origins". ${ }^{6}$ It will be argued below that these assertions are based on a misconception of the term mamlük as used in Mamluk sources. Servile status was not considered a source of pride; on the contrary, it seems to have been considered degrading and manumitted slaves with aspirations made great efforts to repress the servile phase of their life.

\section{The meaning of the term mamlük}

We often come across declarations of manumitted slaves to the effect that they are "the mamlüks of the sultan" (nahnu mamālìk al-sul$t \bar{a} n)$. However, when checking the context in which these expressions appear, we find that they are meant to express obedience and subordination to the ruler and not slave status or pride in slave (mamlük) descent. Often, when a Mamluk amir rebels or is suspected of being disloyal, he expresses his (real or dissimulated) subordination to the ruler with the words "I am a mamlūk of the sultan and obey him" (ana mamlük al-sultān wa-tahta țăatihi). ${ }^{7}$ The connection between the ex-

3 Richards, "Mamlūk Amirs and Their Families", p. 33.

${ }^{4}$ Irwin, "Factions in Medieval Egypt", p. 240.

5 Northrup, "The Bahrī Mamlūk Sultanate", pp. 245, 251.

6 Amitai, "The Mamiūk Institution", p. 62; Amitai, "Military Slavery in the Islamic World", p. 10.

7 See for example al-Ṣafadī, A'yān al-'Așr, vol. 1, p. 640. 
pression mamlük/mamālìk al-sultân and obedience $\left(t \bar{a}^{\prime} a h\right)$ is clear in many other cases. ${ }^{8}$ A Mamluk amir might also designate himself the mamlük of a fellow khushdāsh in order to express subordination and obedience to him. For example, after al- ${ }^{\circ} \bar{A}$ dil Kitbughā (d. 702/1302) was deposed by al-Manșūr Lājīn (d. 698/1299), he is quoted as saying of Lajīn that "he is my comrade and I am his mamlük who obeys him" (huwa khushdāshī wa-anā mamlūkuhu wa-tahta amrihi). ${ }^{9}$ In other cases it is clear that mamlüks expressing obedience and subordination with the expression "we are your mamlüks who obey you" (nahnu mamālìkuka wa-'alà ță'atika) do not address their master, but rather a patron whom they serve. ${ }^{10}$ Moreover, even free persons might express obedience by using the expression "we are mamlūks" (nahnu mamālìk). ${ }^{11}$ Al-Maqrīzì (d. 845/1441) provides a very clear example of the link between the expression nahnu mamālìk and total subordination. When the rebel Jukam min 'Awad (d. 809/1406) claimed the title of sultan in the year 803/1400 he tried to reassure al-Nāșir Faraj (d. $815 / 1412$ ) that he and his followers were not opposing him but the amir Nawrūz al-Hāfizịi (d. 817/1414), saying: "We are the mamlūks of the sultan... had he wanted to kill us we would not have opposed his command" (nahnu mamālìk al-sulțān... wa-law arāda qatlanā mā khālaf$n \bar{a} h u) .{ }^{12}$ While such expressions are clearly hyperbole (or even plain lies), the phrase "we are mamlüks" (nahnu mamālìk) is almost always meant to express subordination and obedience. It often appears in the course of revolt or when an amir is suspected of planning one. It never expresses pride in mamlük status or origin.

Many times the term mamlük is used to convey the fact that a person is a ruler's or a patron's servant, and not his slave. In the same manner, the term ustā $d h$ is used to denote a patron and not a master. ${ }^{13}$ For example, the Khawārizmìyah, a group of free mercenaries, ad-

${ }^{8}$ See for example Ibn Taghrībirdī, al-Nujūm al-Zāhirah, vol. 8, pp. 11, 180; al-

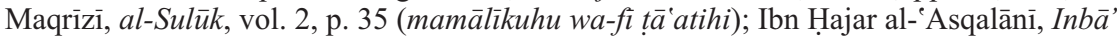
al-Ghumr, vol. 2, p. 333 (mamlūkuka muțì' amrika); and see also al-Ṣafadī, A'yān al-'Așr, vol. 2, p. 257 (ghulām mawlānā al-sulțān wa-nā'ibuhu); Ibn Ājā, Ta'rīkh al-Amìr Yashbak al-Z̄āhirī, p. 137.

9 Zetterstéen, Beiträge zur Geschichte der Mamlūkensultane, p. 42.

${ }^{10}$ Qaratāy al-'Izzī al-Khāzindārī, Ta'rīkh Majmū' al-Nawādir, p. 273.

11 See for example Qarațāy al-'Izzī al-Khāzindārī, Ta'rīkh Majmū' al-Nawādir, p. 233; al-Nuwayrī al-Iskandarānī, Kitāa b al-Ilmām, vol. 6, p. 382.

12 Al-Maqrīzī, al-Sulūk, vol. 3, p. 1062.

13 See for example Ibn Taghrïbirdī, al-Nujūm al-Zāhirah, vol. 15, p. 521. 
dressed the Ayyubid sultan al-Ṣālih Ayyūb (d. 647/1249) as his mamlūks. Qarațāy al-'Izzī al-Khāzindārī (d. after 708/1308) mentions that al-Ṣālih Ayyūb "enslaved them with money" (ista'badahum bi-lamwa $l),{ }^{14}$ and the context makes it clear that al-Sālih Ayyūb bought their services and that Qarațāy al-'Izzī al-Khāzindārì is referring to patron-client ties based on exchange relationships: favors of the patron (ni mah/ihsān) in return for service (khidmah). ${ }^{15}$ From the above-mentioned example it is clear that this usage of the term mamlu $k$ was not unique to the Mamluk period. ${ }^{16}$ The same Khawärizmìyah make it clear that the usage of the term mamlük is strongly related to service (khidmah) and obedience (ța $\left.{ }^{\prime} a h\right)$, when they say to al-Șālih Ayyūb: "We came to serve you and we are your obedient mamlūks" (nahnu qad hadarnā ilà khidmatika wa-naḥnu mamālìkuka wa-taḥta tóa $\left.{ }^{\prime} a t i k a\right) .{ }^{17}$ They highlight the metaphorical meaning of the term mam$l \bar{u} k$ in this case, denoting servitude and not slavery, by adding that they are "slaves of the Ayyubids" ( $a b \bar{\imath} d$ li-Banī Ayyūb) ${ }^{18}$ In a similar manner, the free Turkmen amir, Qarājah bin Dhū l-Ghādir (d. 754/1353), who aspired to the post of governor of al-Abulustayn in the year $738 / 1337$, expressed his request by saying that he "wishes to be the

${ }^{14}$ Qarațāy al-'Izzī al-Khāzindārī, Ta'rīkh Majmū' al-Nawādir, p. 65.

15 We can find another example for the usage of the term mamlük related to service (khidmah) given in return to favors (ihsān) in the words of the Bahriyah to the ruler of Anatolia (șạib al-rūm): "If you will be pleased of us and give us from your favors we will be your mamlūks" ( a-in ahsanta ilaynā wa-radìta binā fa-nahnu mamālìkuka), Qarațāy al-'Izzī al-Khāzindārī, Ta'rīkh Majmū' al-Nawādir, p. 145; and see also Ibn Qāḍī Shuhbah, Ta'rìkh Ibn Qādì Shuhbah, vol. 4, p. 302; for the connection between the term mamlūk, favors and total subordination, see Mufaḍdal b. Abī al-Faḍ̄'il, al-Nahj al-Sadìd, p. 379; for the importance of patron-client relationships, ihsān and ni mah in the Mamluk Sultanate, see Van Steenbergen, Order out of Chaos, pp. 57-75; for their importance prior to the Mamluk period, see Mottahedeh, Loyalty and Leadership, pp. 40-42, 72-93.

${ }^{16}$ For another example of a usage of the term mamlük expressing obedience and service concerning the Ayyubid period, see Qarațāy al-'Izzī al-Khāzindārī, Ta'rīkh Majmū' alNawādir, p. 78. In a similar manner, during the 'Abbāsid period, servile terminology (mawlā, ghulām, and more rarely 'abd) was used to express servitude and loyalty, see for example Golden, "Khazar Turkic Ghulāms", pp. 285-287 (especially page 286); Beckwith, "Aspects of the Early History", p. 38; Pipes, "Mawlas", p. 224; Crone, "Mawlā", p. 881; and see also Golden, "The Terminology of Slavery".

17 Qarațāy al-'Izzī al-Khāzindārī, Ta'rīkh Majmū' al-Nawādir, p. 94; for another

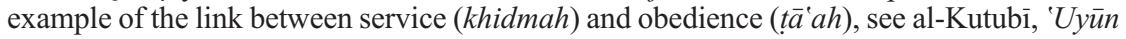
al-Tawārīkh, p. 223.

${ }^{18}$ For a similar case, see Qarațāy al- 'Izzī al-Khāzindārī, Tà'rīkh Majmū' al-Nawādir, p. 155.

Al-Qanțara XXXIV 1, 2013, pp. 7-34 ISSN 0211-3589 doi: 10.3989/alqantara.2013.001 
sultan's servant (mamlük) in that land" (yas'alu an yakūna mamlük alsultān fì tilka al-ard ). ${ }^{19}$

We also come across instances in which mamlüks, after being manumitted, offer their service to persons other than their masters, in words similar to those of Qarājah bin Dhū al-Ghādir. ${ }^{20}$ In both the Turkish and the Circassian periods, it was common enough that sons of mam$l \bar{u} k \mathrm{~s}$, Mongol immigrants (wäfidìyah) or other free persons, were listed among the members of the sultan's mamlüks (mamālìk al-sulțān) or that of an amir. ${ }^{21}$ We also find references to Christian bureaucrats who converted to Islam as servants (mamlüks) of the sultan. ${ }^{22}$ Sometimes the sultan's khushdāshìyah refer to themselves as his mamlüks ( $m a-$ $m \bar{a} l \bar{k} k$ al-sultân), and in these instances it is clear that the term mamlük denotes servitude rather than servile status. ${ }^{23}$ In addition, the term mam$l \bar{u} k$ was frequently used as part of the protocol of the civilian and military elite, in order to express subordination and low rank. We have evidence that at times civilians found this term degrading and refused to use it. ${ }^{24}$ According to Nasser Rabbat the meaning of the term mamluk was transformed in the beginning of the Mamluk period from a warrior-slave who was subjugated all his life to his master, to one destined to be manumitted and promoted in the ranks of the military. ${ }^{25}$ It turns out that the term, even prior to the period of the Mamluk Sultanate, also simply denoted a servant.

19 Al-Shujā'̄i, Ta'rīkh al-Malik al-Nāṣir Muhammad, p. 22; for a similar case, see alSakhāwī, Wajīz al-Kalām, vol. 2, p. 657.

20 See for example Qarațāy al- 'Izzì al-Khāzindārī, Ta'rīkh Majmū' al-Nawādir, p. 164.

21 See for example Qarațāy al-'Izzī al-Khāzindārī, Ta’rīkh Majmū' al-Nawādir, pp. 284-285; Ibn Taghrībirdī, al-Manhal al-Ṣäfi, vol. 5, p. 285; Ibn Taghrībirdī, al-Nujūm alZähirah, vol. 7, p. 46, vol. 9. pp. 13-14; Ibn Taghrībirdī, Hawādith al-Duhūr, vol. 1, p. 390; Ibn al-Furāt, Ta'rīkh Ibn al-Furāt, vol. 7, p. 146; al-Nuwayrī, Nihāyat al-Arab, vol. 32, p. 236; Ibn Qāḍi Shuhbah, Ta’rīkh Ibn Qā dị Shuhbah, vol. 1, p. 368; Ibn Duqmāq, al-Nafhah al-Miskīyah, p. 75; Ibn Duqmāq, al-Jawhar al-Thamīn, p. 447; al-Maqrīzì, Al-Sulük, vol. 2, p. 77, vol. 4, p. 1069; Ibn Hajar al-'Asqalānī, Inbā' al-Ghumr, vol. 1, p. 219; Zetterstéen, Beiträge, p. 144; Baybars al-Manșūrī, Zubdat al-Fikrah, p. 231; al-Yūsufī, Nuzhat al-Nāzir, p. 234; al-'Aynī, al-Sulțān Barqūq, p. 496.

22 See for example al-Yūsufì, Nuzhat al-Nāzir, p. 130.

23 Al-Yūsufi, Nuzhat al-Nāzir, p. 166.

24 See for example Ibn Taghrībirdī, al-Manhal al-Șāfi, vol. 8, p. 163; al-Șafadī, A'yān al-'Assr, vol. 4, p. 504; at times the protocol's terms infiltrated into the spoken language, see for example al-Ṣafadī, A'yān al-'Așr, vol. 4, p. 197.

25 Rabbat, "The Changing Concept of Mamlūk", p. 97; I will discuss below the issue of manumission more thoroughly. 
By now it should be clear that the term mamlük denotes obedience, servitude and subordination at least as much as it denotes slave origin and slave status. It is never used to express pride in slave origin. A misinterpretation of the term mamālìk al-sulțān led scholars to argue that free immigrants (wâfidìyah) were refused promotion to high ranking offices because they were not slaves. Al-Maqrīzì has Baybars alJāshankīr (d. 709/1310) address an immigrant amir (wäfid) by the name of Sanjar al-Barawānī (d. 731/1330) as follows:

You are a person who was expelled, an immigrant. How can you think that your status and that of mamālìk al-sulțān is equal?" (anta wāhid manfi, wäfidì, taj'alu nafsaka mithla mamālìk al-sulțān?). ${ }^{26}$

David Ayalon saw in this text evidence that the wäfidiyah were discriminated against for not being slaves; however, as already mentioned, the term mamālìk al-sulțān denotes servitude, subordination and obedience, and not only slave origin. Al-Maqrīzi emphasizes that the immigrant is an expelled person, that is, one who abandoned his previous master, and so betrayed him. In this context, the meaning of the expression mamālìk al-sultān is "the obedient servants of the sultan".

The wäfidiyah were perceived as a treacherous, disloyal and untrustworthy element in the Mamluk society. They were accused of conspiring against Kipchak Sultans, of collaborating with the Mongol Ilkhans, or of trying to escape to the Ilkhan's territories. ${ }^{27}$ They were denied promotion because they had betrayed their previous masters, by immigrating to the Sultanate, and not because they were not slaves. In a similar manner, al-Maqrīzì mentions that when al-Nāșir Muhammad b. Qalāwūn (d. 741/1341) decided to promote Oirat immigrants, who had served the amirs before abandoning them and becoming his servants, al-Nāșir Muhammad's mamālīk al-sulțān made him change his mind after protesting: "They harshly criticized and condoned them for betraying their masters, and said that they are no good" (aktharu

26 Al-Maqrīzī, al-Sulūk, vol. 2, p. 22; and see also David Ayalon, "The Wafidiya in the Mamluk Kingdom”, p. 93; Ayalon maintains that Sanjar al-Barawānī was not an immigrant, but there is evidence that he might have been a wäfid from Anatolia, al-'Aynī, 'Iqd al-Jumān, vol. 2, p. 166.

${ }^{27}$ See for example al-Dhahabī, al-Mukhtār min Ta'rīkh Ibn al-Jazarī, p. 305; Ibn Kathīr, al-Bidāyah wa-l-Nihāyah, vol. 13, p. 268; Ibn Shaddād, Ta'rīkh al-Malik al-Z̄āhir, pp. 104-105; al-Maqrīzī, al-Sulūk, vol. 2, pp. 67, 87; al-Șafadī, al-Wāfì bi-l-Wafâyāt, vol. 24, pp. 178-179. 
min dhammihim wa-l-'ayb 'alayhim bi-kawnihim khāmarū 'alà asātidhahum wa-annahum lā khayr fihim). ${ }^{28}$ Also in this case, the wäfidìyah were accused of being disloyal and untrustworthy (this time in the territories of the Sultanate), and hence unworthy of promotion. On another occasion, when al- $\bar{A}$ Adil Kitbughā decided to promote the Oirat immigrants, he was accused of promoting them "not according to the norms [of promotion], for he promoted them over the senior amirs of the state" ('alà ghayr al-qiyās, fa-qaddamahum 'alà akäbir al-dawlah). ${ }^{29}$ In this case the complaint was that the immigrants served too short a period for being promoted. Nowhere it is mentioned that their not being slaves was problematic, an assertion that could only arise through a misinterpretation of the term mamālìk al-sulțān.

\section{Was slave status an elite status and a source of pride?}

That said it should still come as no surprise that none of the mam$l \bar{u} k$ sultans saw fit to boast of his slave origin, or to claim that his legitimacy to rule was based on such an origin. To the contrary, mamlük sultans were in great pains to rid themselves of the negative connotations attached to their servile past, by associating themselves with established dynasties or by claiming an exalted origin. The mamlüks were criticized for their servile origin by the local population and by their external enemies. The Ilkhans treated the mamlük sultans as inferiors for the latter's humble descent (nasab). ${ }^{30}$ In response, the mamlūks tried to highlight their relative advantage over the Ilkhans - their being Muslims and defenders of Islam $(j i h \bar{a} d) .{ }^{31}$ In general, the local population was also not pleased with mamlük rule ("they generally did not want that one of the mamlūks will be the ruler" - kāna 'àdatuhum an lā yurìdūna an yaliya al-mulk ahad min al-mamālìk),

28 Al-Maqrīzī, al-Sulūk, vol. 2, p. 83.

29 Baybars al-Manșūī, Zubdat al-Fikrah, p. 330.

${ }^{30}$ See for example al-Maqrīzì, al-Sulūk, vol. 1, p. 427; Ibn Duqmāq, Nuzhat al-Anām, p. 261; Broadbridge, Kingship and Ideology, pp. 13, 29, 33-34; Aigle, "The Mongol Invasions of Bilād al-Shām", p. 104; Amitai, Mongols and Mamluks, p. 36.

${ }^{31}$ Broadbridge, Kingship and Ideology, pp. 12-13, 27-28, 65, 74; Broadbridge shows how the Mamluk ideology changed in response to the ideological challenge set by the Ilkhans, and how each side tried to utilize his relative advantage in each phase of the struggle, see for example Broadbridge, Kingship and Ideology, pp. 38-42; for Franks' criticism of the mamlūks for deposing a king's son, see al-Dhahabī, Duwal al-Islām, pp. 154-155. 
and there is evidence that they supported (sometimes physically) the Qalawunids against mamlūk amirs trying to take the reins of power from them. ${ }^{32}$ The mamlukss could not ignore such perceptions. ${ }^{33}$

Al-Mu izz Aybek (d. 655/1257), the first mamlūk sultan, based his legitimacy on his marital ties with Shajar al-Durr, al-Șālih Ayyūb's widow. Shajar al-Durr even claimed that she was the one who gave Aybek the reins of power. ${ }^{34}$ In early Mamluk sources, al-Mu izz Aybek and his son al-Manșūr 'Alī are considered to be Ayyubid kings. ${ }^{35}$ In later sources, it is mentioned that Aybek had to spent great sums of money in order to convince the local population, that said to him "we want only a sultan from an established house, born as a leader" (l $\bar{a}$ nurìdu illā sultạnan ra'ìsan mawlüdan 'alà fitrah), to comply with the rule of a mamiūk sultan (man massahu al-riqq). ${ }^{36}$

Al-Muzaffar Quțuz (d. 658/1260), the second mamlūk sultan, claimed that he was a relative of the Khawarizmian king Jalāl al-Dīn Khawārizm Shāh. In a biographical anecdote it is related that one day Qutuz' master beat him and cursed his fore-fathers. Quțu, who burst into tears, explained that he was not crying because of the beating, but because his fore-fathers were cursed. When told that he had no reason to cry on account of his fore-fathers, for he was just "a Turkish mamlük, infidel son of infidels" (mamlük turki käfir b. käfirìn), he replied that

32 Shoshan, Popular Culture in Medieval Cairo, pp. 52-65; Ibn Taghrībirdī, al-Nujūm al-Zāhirah, vol. 8, pp. 170-175.

33 Al-Safadi provides us with an anecdote that illustrates how Mongol attitudes affected the Mamluks. When Qawșūn al-Nāṣirī deposed Abū Bakr b. al-Nāṣir Muhammad, the amir Ṭashtamur al-Sāqi is quoted saying that the amirs pledged loyalty to al-Nāșir Muhammad and his descendants, so how do they now depose his son and expel his other descendants. He concludes by saying: "what will the enemy think of us?" (aysh yaqūlu

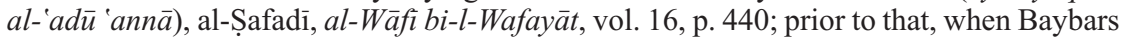
al-Jāshankīr deposed al-Nāșir Muhammad, Ibn Taghrībirdī has al-Nāṣir Muhammad threat to escape to the Tatars and complain of his deposal, Ibn Taghrïbirdī, al-Nujüm al-Zāhirah, vol. 8, p. 244. The Mongols criticized the Mamluks for deposing sultans too frequently, Broadbridge, Kingship and Ideology, pp. 74, 79.

${ }^{34}$ Al-Makin, Akhbār al-Ayyūbìyinn, p. 43; when the senior amir al-Fāris Aqțāy (d. 652/1254) married an Ayyubid princess people found this improper, Ibn al-Dawādārì, Kanz al-Durar, vol. 8, pp. 30-31; this marital tie strengthened Aqtây's claim for power on the one hand, but on the other it made al-Mu'izz Aybek suspicious of him, what eventually led to his murder by Aybek, Ibn al-Dawādārī, Kanz al-Durar, vol. 8, p. 25; al-Nuwayrī, Nihāyat al-Arab, vol. 29, p. 430.

35 Baybars al-Manșūrī, Mukhtār al-Akhbār, p. 10; Louis Cheikho, Petrus ibn Rahib, pp. 99-100; for remnants of such perception, see Ibn Duqmāq, al-Nafhah al-Miskiyah, p. 196.

${ }^{36}$ Ibn Taghrïbirdī, al-Nujūm al-Zāhirah, vol. 7, p. 13; for Bedouin opposition to mam$l \bar{u} k$ rule in the days of Aybek, see al-Maqrīzì, al-Sulūk, vol. 1, p. 386. 
he was the relative of Khawārizm Shāh. ${ }^{37}$ This anecdote illustrates that $m a m l \bar{u} k$ origin was far from being a source of pride, and that mamlüks tried to repress such an origin and replace it with a more exalted one. ${ }^{38}$

Al-Zāhir Baybars (d. 676/1277), who was criticized for being a slave by the local population and by the Sultanate's external enemies, ${ }^{39}$ tried to associate himself to established dynasties in several ways: he asked the Qāọī Ibn Khallikān (d. 681/1282) to forge a Genghisid genealogy for him $;{ }^{40}$ he married a Khawarizmian princess whose family was related by marriage to al-Șālih Ayyūb; ${ }^{41}$ his relative, Baysarī al-Shamsī (d. 698/1298), also established marital ties with the Ayubbids; ${ }^{42}$ Baybars also related himself to al-Șālih Ayyūb by adopting his nisbah:43 he established marital ties with families of senior Mongol immigrants $;{ }^{44}$ and he connected himself symbolically to the Saljuqs. ${ }^{45}$ In the popular treatise Sirat Baybars, Baybars is said to be the son of the king of Khurasan, born as a Muslim by the name of Mahmūd, sold into slavery, adopted by al-Ṣālị Ayyūb and designated his heir. According to Thomas Her$\mathrm{zog}$, the purpose of this treatise was to legitimize the rule of mamlüks. ${ }^{46}$

37 See for example al-Nuwayrī, Nihāyat al-Arab, vol. 29, p. 480; Ibn al-Dawādārī, Kanz al-Durar, vol. 8, p. 40.

${ }^{38}$ Holt maintains that young mamlūks with aspirations tried to legitimize these aspirations by forging an exalted genealogy. He adds that it might be that Qutuz' story circulated among his comrades, and when he ascended the throne it became a legitimizing propaganda, Holt, "Prediction or Propaganda?", p. 136.

${ }^{39}$ See for example Ibn Duqmāq, Nuzhat al-Anām, p. 256; Ibn Taghrībirdī, al-Nujūm al-Zāhirah, vol. 7, p. 145; Ibn Kathīr, al-Bidāyah wa-l-Nihāyah, vol. 13, p. 254; al-Nuwayrī al-Iskandarānī, Kitāb al-Ilmām, vol. 4, p. 81; Broadbridge, Kingship and Ideology, pp. 13, 29, 33-34; Amitai, Mongols and Mamluks, p. 36.

40 Al-Ṣafadī, al-Wāfi bi-l-Wafayāt, vol. 7, p. 311.

${ }^{41}$ Ibn Duqmāq, Nuzhat al-Anām, p. 171; on al-Șālih Ayyūb's marital ties with the Khawarizmian dynasty, see Ibn al-Furāt, Tà'rìkh Ibn al-Furāt, vol. 7, p. 90; al-Șafadī, alWāfi bi-l-Wafâyāt, vol. 9, p. 353; al-Yūnīnī, Dhayl Mir'āt al-Zamān, vol. 4, pp. 32-34; alBirzālī, Tà'rīkh al-Birzālì, vol. 2, p. 45.

${ }^{42}$ Al-Șafadī, al-Wâfí bi-l-Wafâyāt, vol. 21, p. 339.

${ }^{43}$ Clifford, "State Formation and the Structure of Politics in Mamluk Syro-Egypt", p. 130; on the importance the mamlūks ascribed to al-Șālih Ayyūb as a legitimizing figure, see for example Stewart, "Between Baybars and Qalāwūn", p. 48; Thorau, The Lion of Egypt, p. 98

${ }^{44}$ Ibn al-Furāt, Ta'rīkh Ibn al-Furāt, vol. 7, p. 90; al-Nuwayrī, Nihāyat al-Arab, vol. 30, p. 368; al-Maqrīzī, al-Sulūk, vol. 1, p. 640, vol. 2, p. 337; Ibn Shaddād, Ta'rīkh alMalik al-Zāhir, p. 144.

${ }^{45}$ Broadbridge, Kingship and Ideology, p. 38.

${ }^{46}$ Herzog, "Legitimität durch Erzählung", pp. 251-252; and see also Elbendary, “The Sultan, The Tyrant, and The Hero", pp. 151-152. 
Al-Manșūr Qalāwūn (d. 689/1290) boasted of his exalted ethnic origin and his marital ties to the family of al-Zāhir Baybars. ${ }^{47}$ Al-Manșūr Làjīn (d. 698/1299) made use of the fact that he was married to al-Zāanir Baybars' daughter, and therefore also indirectly related to the Qalawunid dynasty, in order to legitimize his rule. Al-Nuwayrī (d. 733/1333) mentions that shortly after becoming sultan, he brought the exiled Khiḍr b. Baybars and his mother from Constantinople to Egypt, because he was married to the daughter of Baybars. ${ }^{48} \mathrm{He}$ also brought to Egypt the coffin of Salāmish, al-Z̄āhir Baybars' exiled son. Al-Muzaffar Baybars al-Jāshankīr (d. 709/1310), the relative of Al-Manșūr Lājīn, also emphasized his indirect tie to the family of al-Zāhir Baybars. In his days, Khidr b. Baybars was allowed to leave the fortress and live in the palace of the amir Aqush al-Afram, a relative of Baybars alJāshankīr. ${ }^{49}$

Al-Zāhir Barqūq (d. 801/1399), who after al-Muẓaffar Baybars alJāshankīr was the first mamlūk sultan to hold the reins of power in about a hundred years, was criticized from all sides for being a slave..$^{50}$ In response he attached himself to the Qalawunid dynasty ${ }^{51}$ and boasted of his ethnic origin. ${ }^{52}$ Other Circassian mamlük sultans, such as alMu'ayyad Shaykh (d. 824/1421) and al-Z̄āhir Țațar (d. 824/1421), boasted of an exalted ethnic origin, and Shaykh even claimed to be a descendant of Circassian kings. ${ }^{53}$ In some of the biographies of mamlük amirs in the Circassian period it is mentioned that they were of inferior origin (radī' al-așl). ${ }^{54}$ From this we learn that a mamlūk's descent was a matter of importance, and that an exalted origin was a source of pride.

${ }^{47}$ See for example Shāfi ' b. 'Alī, al-Fadl al-Ma'thūr, p. 25; Baybars al-Manșūrī, Zubdat al-Fikrah, p. 177; al-Qalqashandī, Șubh al-A'shā, vol. 14, pp. 341-344.

${ }^{48}$ Al-Nuwayrī, Nihāyat al-Arab, vol. 31, p. 329; see also al-Dhahabì, al-Mukhtār min Ta'rīkh Ibn al-Jazarī, p. 376.

${ }^{49}$ Ibn Taghrïbirdī, al-Nujūm al-Zāhirah, vol. 8, p. 229.

50 See for example al-Malatî, Nayl al-Amal, vol. 2, p. 212; Ibn Qāḍi Shuhbah, Ta'rīkh Ibn Qādì Shuhbah, vol. 1, p. 472; Ibn Taghrībirdī, al-Nujūm al-Zāhirah, vol. 11, p. 207, vol. 12 , p. 57.

51 Al-Malatī, Nayl al-Amal, vol. 2, p. 233; al-Sakhāwī, al-Daw' al-lāmi’ li-Ahl alQarn al-Tāsi', sec. 12, p. 132; al-Jawharī, Nuzhat al-Nufüs, vol. 1, p. 127; Van Steenbergen, Order out of Chaos, pp. 84-85. p. 223.

${ }^{52}$ Broadbridge, Kingship and Ideology, p. 184; Ibn Iyās, Badā'í al-Zuhūr, vol. 1,

53 Al-'Aynī, al-Sayf al-Muhannad, pp. 47-48; al-'Aynī, al-Rawd al-Zāhir, pp. 5-6; on the two treatises see Holt, "Literary Offerings", pp. 8-12.

${ }^{54}$ See for example al-Sakhāwī, al-Ḍaw' al-lāmi', sec. 10, pp. 345-346. 
Like mamlūk sultans, mamlūk amirs did not boast of their servile origin and tried to claim for themselves an exalted descent. Qawșun al-Nāșirī (d. 741/1341) was proud of not being a real slave (mamlük) and for not having had to undergo the normal route of training in the barracks and slow promotion. ${ }^{55}$ Sources of the Turkish period mention the high ranking position of the fathers of Mongol war captives who became senior amirs in the Sultanate. ${ }^{56}$ For example, Salār al-Manșūrī's (d. 710/1310) father was in charge of the hunt (amī shikār) in the court of the ruler of Anatolia (săhib al-rüm), and we know that when Qibjaq al-Manșūrī (d. 710/1310) fled to the Ilkhanid territories he met his father and brothers who served at the court of the Mongol khan. ${ }^{57} \mathrm{We}$ also know that Aytamush al-Muhammadì (d. 736/1336), a high ranking Mongol amir, was descended from an exalted Mongol lineage (the circumstances of his arrival into the Sultanate are not mentioned in the sources).$^{58}$ It is certainly reasonable that these amirs were proud of their exalted origin, which was quite likely taken into consideration when they were promoted. ${ }^{59}$ Muslim ("free") origin was also a source of pride, and we have evidence that some mamlüks (like Qutuz) claimed to be Muslim war captives. ${ }^{60}$ Some of the mamlüks even claimed to be descendants of the Prophet (ashräf). ${ }^{61}$ At times the status of the mam$l \bar{u} k s$ in their homeland was remembered, and mamlūks who came from a humble background were ridiculed. ${ }^{62}$ Even in the "more mamlūk"

55 See for example Ibn Taghrībirdī, al-Nujūm al-Zāhirah, vol. 10, p. 47; Ibn Duqmāq, al-Nafhah al-Miskiyah, p. 143. Interestingly, when Qawșūn wanted that mamālìk al-sulțān will serve him, he faced a strong objection from the mamāli $k$ who claimed that they are not willing to serve someone who is a mamlūk like themselves, Ibn Taghrïbirdī, al-Nujūm al-Zāhirah, vol. 10, p. 25. From this we learn that, at least during the long reign of the Qalawunids, the perception was that the ruler should be a member of an established family.

${ }^{56}$ We also know that some of the captives were high ranking officers in the Mongol army, al-Maqrīzì, al-Sulūk, vol. 2, p. 162.

${ }_{57}$ Baybars al-Manșūrī, Zubdat al-Fikrah, p. 153; Ibn Taghrībirdī, al-Manhal al-Ṣâfí, vol. 6, pp. 13-15; Ibn al-Dawādārī, Kanz al-Durar, vol. 8, p. 376.

${ }^{58}$ Little, "Notes on Aitamiš, a Mongol Mamlūk", p. 391.

${ }^{59}$ In a similar manner, in the Circassian period we are informed that Bujās al-Nawrūzì (d. 803/1400), the high ranking Circassian amir, was a respected man in his homeland, Ibn Ḥajar al-'Asqalānī, Inbā' al-Ghumr, vol. 4, p. 270.

${ }^{60}$ See for example Ibn al-Furāt, Ta'rìkh Ibn al-Furāt, vol. 8, p. 216; al-'Aynī, 'Iqd alJumān, vol. 4, p. 292.

${ }^{61}$ See for example al-Malatī, Nayl al-Amal, vol. 5, p. 249; al-Ṣafadī, al-Wāfì bi-lWafayāt, vol. 8, p. 370.

${ }_{62}$ Al-Șafadī, A'yān al-'Așr, vol. 2, p. 114; and see also Baybars al-Manșūrī, Zubdat al-Fikrah, p. 105. 
Circassian period, service in the barracks as a mamlūk was certainly not a source of pride. We hear, for example, that when the Sultan alZāhir Jaqmaq (d. 858/1453) bought the grandson of the brother of the senior amir Yashbak min Salmān Shāh al-Mu'ayyadī (d. 878/1473), he exempted him from service in the young mamlūks' barracks out of respect for his uncle ("raqqāhu 'an dhälika ikrāman li- 'ammihi"). ${ }^{63}$

Far from being a source of pride, there is evidence that being a slave was in fact considered degrading. When al-Ashraf Khalīl b. Qalāwūn (d. 693/1293) wanted to humiliate the amir Lājīn al-Manșūrī, he made him a mamlūk of the amir Baydarā al-Mansuurī (d. 693/1293). According to Baybars al-Manșūrī (d. 725/1325), Làjīn became Baydarā's slave and not his servant (wahabtuka lahu haqqan li-tașìra mamlūkan riqqan). ${ }^{64}$ Mamluk writers usually differentiate quite clearly between rank-and-file mamlūks and amirs, ${ }^{65}$ and the expression "the amirs and the mamlüks" (al-umarā' wa-l-mamālìk) is quite common in Mamluk sources. Whereas amirs, who were generally manumitted slaves, were respected, we come across expression of contempt towards simple mamlüks. For example, when the amir Aqbāy al-Hājib (d. 805/1402) beat one of the amir 'Alībāy al-Zāhirì's (d. 800/1397) mamlūks, 'Alībāy complained to al-Zāhir Barqūq, but Barqūq dismissed the complaint with the words "am I supposed to beat Aqbāy on account of a [simple] mamlūk?" (adribu Aqbāy li-ajli mamlūk?) ${ }^{66}$

According to Shaun Marmon, “...the enslaved individual suffered a kind of legal and social metamorphosis. He left the realm of human beings and entered the realm of commodities thus losing his legal capacity to act of and for himself" ${ }^{67}$ Marmon is referring to household slaves, but it seems that the status of the military slaves (mamlüks) was not much different. At times, it is implied that, unlike amirs, mamlūks were not considered human beings. When the amir Al'akuz al-Nāsirīi (d. 738/1337) cursed another amir, al-Nāșir Muhammad is quoted as saying to him: "How do you allow yourself to call an amir, like you, a pimp? You were just a page in the stables until I promoted you and

63 Al-Sakhāwī, al-Ḍaw’ al-lāmi, sec. 10, pp. 270-271; and see also Ayalon, L'esclavage du Mamelouk, pp. 22-24.

${ }^{64}$ Baybars al-Manșūrī, Zubdat al-Fikrah, p. 310.

65 See for example Ibn Șașrā, al-Durrah al-Muḍ̄'ah, p. 67.

66 Ibn Taghrībirdī, al-Manhal al-Ṣâfi, vol. 8, p. 247.

67 Marmon, "Domestic Slavery in the Mamluk Empire", p. 3. 
made you a human being" (taqūlu li-amīr mithlaka qawwäd? wa-aysh kunta anta fi-l-isțabl aūshāqī, țalla'tu bi-ka wa-'amaltuka b. Ádam) ${ }^{68}$ Military slaves (mamlüks) are quite often mentioned as part of a deceased amir's estate. ${ }^{69}$ When the Circassian amir Qarā Sunqur alManșūrī (d. 728/1327) was pursued by al-Nāșir Muhammad, he was advised to turn himself in. He refused, claiming that al-Nāșir Muhammad would surely kill him, for he was originally just "a piece of Circassian slave... that was not even worth 300 Dirhams" (qiț'at mamlük jarkasi $\bar{i} . . m \bar{a}$ yasw $\bar{u} 300$ dirham).$^{70}$ This is yet another indication that a slave, not to mention a Circassian slave, was perceived as property and not as a human being.

The master's domination over his mamlüks was total. Masters had the right to prevent their mamlüks from marrying or to arrange a marriage as they wished. ${ }^{71}$ Cases of disobedience by mamlüks were considered a severe breach of the master's honor. ${ }^{72}$ We hear of mamlüks who fled from their masters out of fear. ${ }^{73}$ At times, amirs are praised for not cursing their mamlu $k \mathrm{~s} ;{ }^{74}$ we may thus assume that cursing, humiliation and even beating of mamlüks were not that rare (and see above the story of Qutuz). It is even implied that the master had the right to take his mamlu $k \mathrm{~s}$ ' lives. ${ }^{75}$ A slave's manumission is occasionally compared to release from imprisonment or captivity. For example, when al-Ashraf Khalīl b. Qalāwūn (d. 693/1293) released Baysarī alShamsī after a long period of imprisonment, Baysarī took on Khalīl's nisbah (al-ashrafi), like a manumitted slave, ${ }^{76}$ and the son of the Armenian king, who was released from captivity, is called 'atìq (manumitted slave). ${ }^{77}$ Mamlūks had no separate legal identity and no legal capacity to act on their own; their actions were attributed to their masters. For example, Baybars al-Manșūrī refers to Kitbukhā's mamlūks

${ }^{68}$ Al-Yūsufî, Nuzhat al-Nāzir, p. 307.

69 See for example al-Birzāili, Ta'rīkh al-Birzālì, vol. 4, p. 139.

${ }^{70}$ Ibn al-Dawādārī, Kanz al-Durar, vol. 9, p. 224.

${ }^{71}$ See for example al-Maqrīzì, al-Sulūk, vol. 4, p. 348; Ibn Taghrībirdī, al-Nujūm alZāhirah, vol. 7, p. 328; al-Malatī, Nayl al-Amal, vol. 3, p. 299, vol. 7, p. 415.

72 Al-Maqrīīi, al-Sulūk, vol. 2, p. 399.

73 See for example al-Kutubī, Fawāt al-Wafayāt, vol. 1, p. 115.

${ }^{74}$ See for example Ibn Qāḍi Shuhbah, Ta'rīkh Ibn Qādì Shuhbah, vol. 1, p. 682.

75 Al-Yūsufî, Nuzhat al-Nāzirir, pp. 146-147; al-Maqrīzì, al-Sulük, vol. 3, p. 1062.

${ }^{76}$ Ibn al-Furāt, Ta'rīkh Ibn al-Furāt, vol. 8, pp. 122-123; and see also al-Nuwayrī, Nihāyat al-Arab, vol. 31, p. 215.

${ }_{77}$ Al-Dhahabì, Ta'rìkh al-Islām, vol. 53, p. 120. 
as "his slaves, whose actions are attributed to him" (mamālìkuhu, almansūb sanï'uhum ilayhi). ${ }^{78}$ At times a mamlūk acting on behalf of his master is called 'abd ma'mūr (a legal category that relates to slaves empowered by their masters to act on their behalf), ${ }^{79}$ thus accentuating the mamlūk's lack of legal capacity.

Orlando Patterson defined a slave as a powerless, violently dominated, natally alienated and generally dishonored person, who has no existence without his master. ${ }^{80}$ According to Dror Ze'evi, the near-absolute power of the master was softened by the fact that the relationship between slave and owner sometimes resembled family relations, and especially in the case of elite slavery, integration into the family of the master was a necessary phase.$^{81}$ However, as Richards has already argued, only few especially favored mamlüks were treated as quasi-kin by their masters and his relationship with the mass of them must have been of a more material nature..$^{82}$ Elsewhere I have argued that $m a m l \bar{u} k \mathrm{~s}$ perceived themselves as slaves because of the absence of family ties, and that only an outstanding few succeeded in completely freeing themselves of their slave status and become members of a ruling elite with family ties. ${ }^{83}$ It would thus seem that Patterson's definition fits military slaves (mamlūks) quite nicely. ${ }^{84}$

\section{Slave status and manumission}

Modern scholars have commonly argued that the servile phase in the life of a mamlük was only formal and quite limited in time. It is

78 Baybars al-Manșūrī, Zubdat al-Fikrah, p. 332.

79 See for example Ibn Taghrībirdī, al-Nujūm al-Zāhirah, vol. 15, p. 281.

${ }^{80}$ Patterson, Slavery and Social Death, pp. 4-13.

${ }^{81}$ Ze'evi, "My Slave, My Son", pp. 75-77; and see also Forand, "The Relation of the Slave and the Client to the Master or Patron", pp. 59-66.

82 Richards, "Mamlūk Amirs and Their Families", pp. 34-35. I am preparing now a paper on the relationship between a master and his slaves during the Mamluk Sultanate (generally called by modern scholars 'pseudo-kinship ties'). I will argue that only few favored mamlūks enjoyed a special status in their master's household and, generally, they could enjoy such a status only when the master had no sons.

83 Yosef, "Mamluks and Their Relatives", pp. 63-69.

${ }^{84}$ Amitai maintains that the well-known passage in Ibn Khaldūn's Kitāb al-'Tbar praising the virtues of military slavery indicates that "a positive view toward the phenomenon of military slavery was not unknown in the medieval Islamic world", and that it also "would 
usually maintained that mamlūks were manumitted automatically by the end of their religious and military training, at the age of twenty or less ${ }^{85}$ This is consistent with the claim that military slaves were not slaves in the full sense of the word and that slave status was that of elite. However, at least with respect to the Turkish period, our knowledge about manumission is quite limited, and the commonly held view may well reflect only the situation in the Circassian period. Rabbat is the only scholar who elaborates on the matter (Ayalon did not explore the issue of manumission in any great depth). According to Rabbat, it seems that until the Ayyubid period mamlūks remained slaves even after becoming high ranking military commanders. There is no unequivocal evidence that during the Ayyubid period mamlüks were manumitted automatically at the end of their training. Rabbat assumes, but does not prove, that in the days of al-Z̄āhir Baybars or al-Manșūr Qalāwūn automatic manumission at the end of the training period became the norm. ${ }^{86}$

There is some evidence that at least until al-Nāșir Muhammad b. Qalāwūn's third reign (709/1310-741/1341) mamlūks were not manumitted automatically. Qalāwūn, who was originally the mamlūk of the Ayyubid amir Qarā Sunqur al-Kāmilì (d. 647/1249), became upon the latter's death in the year 647/1249 the slave of al-Ṣālih Ayyūb. He was manumitted later in the same year, shortly before his new master died. ${ }^{87}$ Qalāwūn died in the year 689/1290, at the age of more than sixty or seventy (most sources claim that he was more than sixty years old) ${ }^{88}$ If we estimate his age as sixty-five, then he was manumitted when he

appear to belie somewhat the suggestion of Orlando Patterson that 'social death' was also the status of the military slave of the Islamic world", Amitai, "The Mamlūk Institution", pp. 67-68. However, Ibn Khaldūn puts more emphasis on the benefits that the institution has for Islam rather than for the slaves themselves ("Islam rejoices in the benefit which it gains through them"). Moreover, even when mamlüks who became sultans make a link between their enslavement and their ascendance to power, they clearly regard themselves as being redeemed from slavery, and they consider the servile phase of their lives as a difficult one, see for example al-Nuwayrī al-Iskandarānī, Kitāb al-Ilmām, vol. 4, p. 79; for a detailed discussion, see Yosef, "Mamluks and Their Relatives", pp. 67-69.

${ }_{85}$ See for example Ayalon, L'esclavage du Mamelouk, p. 9; Amitai, "The Mamlūk Institution", p. 62; Rabï', "The Training of the Mamlūk Fāris", p. 162.

${ }^{86}$ Rabbat, "The Changing Concept of Mamlük", pp. 89-93.

${ }^{87}$ Ibn Taghrībirdī, al-Nujūm al-Zāhirah, vol. 7, pp. 325-326; Ibn Iyās, Badā' 'i' alZuhūr, vol. 1, p. 95.

${ }^{88}$ Al-Dhahabī, Duwal al-Islām, p. 189; al-Maqrīzì, al-Sulūk, vol. 1, p. 755; Ibn Taghrïbirdī, al-Nujūm al-Zāhirah, vol. 7, pp. 325-326. 
was about twenty-three. Significantly, he was not manumitted automatically but only upon his master's death. ${ }^{89}$ Salār al-Manșūrī, who was captured in the year 675/1276, was bought by Qalāwūn for his son 'Alī. Upon 'Alī's death in the year 687/1288, he became Qalāwūn's property once again. Salār died in the year 710/1310 at the age of fifty or little less. ${ }^{90}$ If we estimate his age at death as forty-eight, then he was still a slave when he was about twenty-five. He was probably manumitted upon Qalāwūn's death in the year 689/1290, when he was about twenty-seven years old, for his nisbah indicates that Qalāwūn manumitted him.

We know that before al-Nāṣir Muḥammad b. Qalāwūn's third reign some halqah members holding a military estate (iqtă $\left.{ }^{\prime}\right)$ were still slaves (mamālīk ariqq $\left.\bar{a}^{\prime}\right) .{ }^{91}$ These were probably low-ranking mamlüks or mamlūks of amirs, on whom we generally have little information. We have to take into consideration the possibility that such mamlüks were manumitted at a later age..$^{22}$ We also know that in the year 670/1272, al-Zāhir Baybars bought two amirs; therefore, in his time amirs could still be slaves. ${ }^{93}$ Ibn Taghribirdī (d. 874/1470) writes in the biography of the amir Baktamur al-Sāqī al-Nāșirī (d. 733/1332): "Originally, Baktamur was the slave of the Sultan al-Muzaffar Baybars al-Jāshankīr, but then he passed into the hands of the Sultan al-Nāșir Muhammad b. Qalāwūn. Perhaps he only became his servant [and not his slave], for his master, al-Muzaffar Baybars, made him an amir of ten at the end of his reign, and had he not manumitted him he would not have made him an amir" (kāna aṣl Baktamur min mamālìk al-malik al-Muzaffar

${ }^{89}$ For other instances of such manumission, see for example al-Birzālì, Ta'rìkh alBirzālì, vol. 3, p. 361; Ibn al-Mughayzil, Dhayl Mufarrij al-Kurūb, p. 103.

${ }^{90}$ Ibn Taghrībirdī, al-Manhal al-Ṣăfì, vol. 6, pp. 5-13; al-Dhahabī, Dhayl Ta'rīkh alIslām, p. 94.

${ }_{91}$ Al-Nuwayrī, Nihāyat al-Arab, vol. 33, p. 42.

92 Rabbat assumes that amirs followed the sultans and manumitted their mamlūks upon the termination of their training, though he is aware of the fact that the information we have with respect to the mamlüks of the amirs is quite meager, Rabbat, "The Changing Concept of Mamlūk", p. 90.

${ }_{93}$ Al-Maqrīzi, al-Sulūk, vol. 1, p. 597. Interestingly, the editor of the text claims that this part of the text does not make sense, for it is known that mamlüks could not become amirs until manumission. As mentioned, we know very little about manumission in the Turkish period. Ibn 'Abd al-Zāhir mentions that Baybars manumitted in Ramadan 30 slaves apart from whom he had manumitted of his mamlük amirs (ghayr man a'taqa min mamālīkihi al-umarā'), Ibn 'Abd al-Z̄āhir, Al-Rawḍ al-Zāhir, pp. 200-201. Admittedly, the interpretation of this text is not unequivocal. 
Baybars al-Jāshankīr, thumma intaqala ilà-l-malik al-Nāṣir Muhammad b. Qalāwūn, la'allahu bi-l-khidam fa-inna ustādhahu al-Muzaffar Baybars kāna ammarahu 'ashra fi awākhir dawlatihi wa-lawlà annahu

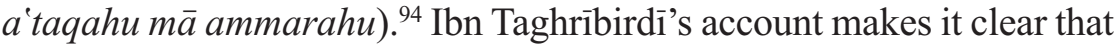
in the Circassian period a slave yet not manumitted could not have become an amir. But apparently he projects this state of affairs onto the Turkish period as well. Baktamur's nisbah is al-Nāșirī, and the nisbah normally goes by the manumitter. Apparently, Ibn Taghribirdì had some further indications that Baktamur was the slave of al-Nāṣir Muḥammad, for he finds this worthy of comment.

We have some evidence that starting from al-Nāșir Muhammad b. Qalāwūn's third reign the enslavement of some of the mamlūks was a mere formality. ${ }^{95}$ This might be related to the fact that starting from this period the Turkish mamlūks were generally sold by their families, who knew about the fine treatment that al-Nāșir Muhammad gave his mamlüks. ${ }^{96}$ Certainly, the enslavement and the conditions under which these mamlüks lived were less traumatic than those of war captives ${ }^{97}$ and it is possible that the servile phase in their lives was considered more formal or more limited in time.

Nevertheless, there is some evidence that until Barqūq's reign at least some of the mamlukks were not manumitted automatically at a young age. ${ }^{98}$ Shāhīn al-Shaykhī (d. 834/1430) was originally a mamlūk of Shaykh al-Safawì (d. 801/1398), but upon his master's death he was bought by Barqūq. Shāhīn was about eighty years old when he died, and therefore he was still a slave at the age of about forty-six. ${ }^{99}$ In the year 785/1383, Aytamush al-Bujāsī (d. 802/1399) was bought by Barqūq and immediately manumitted when the latter discovered that he

94 Ibn Taghrībirdī, al-Nujūm al-Zāhirah, vol. 9, p. 300.

95 The best example of such a formal enslavement is that of Qawșūn al-Nāṣirī. AlNāṣir Muhammad insisted to buy him, even though he was not legally a mamlūk. Al-Nāșir Muhammad sent money to his family and shortly after his "enslavement" Qawșun was promoted and married to one of al-Nāsir Muhammad's daughters. As mentioned, Qawșūn used to boast of this fact. See for example al-Șafadī, A'yān al-'Așr, vol. 4, p. 138; and see page 18 above.

96 Al-Maqrīzī, al-Sulūk, vol. 2, p. 525.

97 Prior to al-Nāṣir Muhammad b. Qalāwūn's third reign many of the mamlūks were war captives.

98 It is usually difficult to estimate the mamlūks' manumission age. Part of the difficulty stems from the fact that the word mamlük has two meanings: slave and servant.

99 Al-Malatī, Nayl al-Amal, vol. 4, p. 296. 
was still a slave, for his original master, Jurjī al-Idrīsī (d. 772/1370), had not manumitted him. After the latter's death the amir Bujās alNawrūzì (d. 803/1400) apparently took him from his heirs and manumitted him illegally. ${ }^{100}$ We know of other instances in which an adult mamlük (sometimes on the verge of a natural death from old age) was still legally a slave, usually due to illegal buying or selling. From such cases we cannot draw any conclusions about mamlüks' manumission age. ${ }^{101}$ Nevertheless, the sources provide us with hints as to the supposed time of Bujās' manumission. Ibn Hijjī (d. 816/1413) comments that it is strange that Aytamush was not manumitted, for his master died in the year 772/1370 and Aytamush had been acting as a free person (yatașarrafu tașarruf al-ahrāar) for a long time. ${ }^{102}$ Ibn Hajar al'Asqalānī (d. 852/1449) also found it strange (min al-gharâ'ib) that when he was bought by Barqūq in the year 785/1383 Aytamush was still a slave, because his master "Jurjī died in the year 772/1370, and Aytamush was acting as a free person for 17 (!) years, although he was still [legally] a slave" (Jurjī māta sanat 772, fa-aqāma Aytamush 17 sanah fi l-riqq yatașarrafu tașarruf al-ahrārr). ${ }^{103}$ These reports indicate that Aytamush was a slave while his master was alive, but was supposed to be manumitted upon Jurjī's death. Apparently his master did not have the chance to do this, or he did it in an illegal manner. When Aytamush died he was almost sixty years old. ${ }^{104}$ If we estimate his age as about fifty-eight, then he was still a slave at the age of twenty-eight. Note that here once again a mamlük's manumission is linked to the death of a master. It seems that, at least during the Turkish period, manumission upon the master's death (probably by a testament) was a common occurrence, and that at least some mamlüks were not manumitted automatically upon the termination of their training period.

The fact that Shāhin and Aytamush were originally mamlūks of amirs might explain their late manumission (see page 23, footnote 92 above). Another explanation, that does not contradict but rather complements the above-mentioned explanation, is that the late age at which Shāhīn and Aytamush were manumitted was due to the fact that they

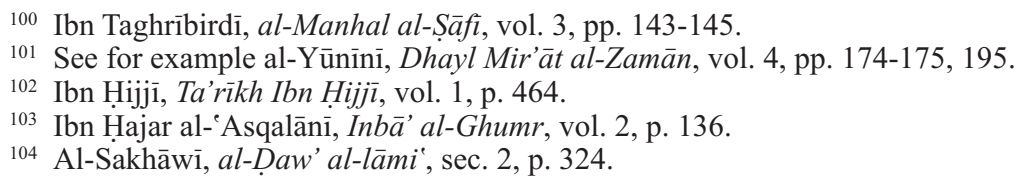


were not Turks - Aytamush was a Circassian and Shāhīn was probably a Rūmī. ${ }^{105}$ There is evidence that during the Turkish period non-Turkish $m a m l \bar{u} k s$ (mainly Circasians and Rūmīs) did not enjoy the same treatment as their Turkish counterparts. Generally, the former were originally Christians, as were many of the Sultanate's enemies, and therefore they were described in negative terms and were subject to discrimination. ${ }^{106}$ Since there is no evidence for the sale of non-Turkish mamlüks by their families during the Turkish period, we may assume that most of them were war captives and therefore their enslavement was more traumatic than that experienced by Turkish mamlüks. ${ }^{107}$ There is also some evidence that non-Turkish mamlūks started families at a later age than their Turkish peers, maybe due to the fact that they were manumitted at a later age. Moreover, as soon as the non-Turkish mamlüks entered the Sultanate, their connection to their families was severed forever. Whereas the Turkish mamlük had the option of becoming a favored mamlukk, marrying into the Qalawunid family, establishing a family while still young, and of bringing his relatives into the Sultanate, this option was almost totally closed to non-Turkish mamlüks. Since the creation of a family was the only way to ultimately shed one's slave status, the non-Turkish mamlüks could not fully leave behind this status even after manumission, and were perceived by their contemporaries as being "more slaves" than the Turkish mamlüks. ${ }^{108}$

Beginning in Barqūq's reign a drastic change took place in mamlūk manumission practices. There is evidence that Barqūq was in the habit ("ka-mā hiya 'ādatuhu”) of buying mamlüks and immediately manumitting them, and apparently this was an innovation. ${ }^{109}$ Indeed, starting in his days, it seems that the mamlüks' period of slavery was limited in time, and mamlüks were manumitted automatically upon the termination of their training, or even immediately after being bought. The ex-

${ }^{105}$ Ibn Taghrībirdī, al-Nujūm al-Zāhirah, vol. 12, p. 187; Yosef, "The Names of the Mamlūks"; Yosef, "Ethnic groups", p. 97.

106 Yosef, "Ethnic Groups", pp. 157-164, 222-223, 303-304.

107 For evidence that during the third reign of al-Nāșir Muhammad non-Turks were enslaved in war while Turks were sold by their families, see al-Maqrīzī, al-Sulük, vol. 2, p. 525; al-'Umarī, Kitāb Masālik al-Abṣār, pp. 69-72. Al-'Umarī states explicitly that the Circassians were war captives.

108 Yosef, "Mamluks and Their Relatives", pp. 56-60; Yosef, "Ethnic groups", pp. 215-223, 246-250, 272-273.

109 Al-Jawharī, Nuzhat al-Nufūs, vol. 1, p. 117. 
pression "bought him and manumitted him" (ishtarāhu wa-a'taqahu) is quite common in sources from the Circassian period. ${ }^{110}$ Another common expression, which, as far as I know, does not appear in texts from the Turkish period, is "manumitted him and made him one of his mamlūks" (a taqahu wa-ja alahu min jumlat mamālìkihi). ${ }^{111}$ As noted above, already in the Turkish period the term mamlük had a double meaning: slave and servant. It seems, however, that in the Circassian period the servile phase in the life of a mamlük was more formal, and he was perceived more as a servant than as a slave. Paradoxically, the expression "manumitted him and made him one of his mamlūks" (a'taqahu waja'alahu min jumlat mamālikkihi) implies that until manumission, the mamlūk (slave) was not considered a mamlūk (servant).

\section{Conclusion}

Even though Mamluk authors emphasize the ethnic origin or language of the Sultanate's ruling elite, modern scholars emphasize its slave status or origin. The commonly held view by modern scholars is that the status of all the mamlüks was that of an elite, and that the mam$l \bar{u} k \mathrm{~s}$ were proud of their slave origin even after manumission. I have argued that this view is in need of modification.

There is no evidence that manumitted mamlüks were proud of their slave status. On the contrary, it seems to have been considered degrading and manumitted slaves with aspirations made great efforts to repress their servile past by claiming an exalted origin or by creating marital ties with established families. The term mamlük has a double meaning: slave and servant, and it frequently expresses subordination, obedience and servitude. When manumitted slaves refer to themselves as "mamlüks of the sultan" they do not express pride in their slave status, but rather their subordination and obedience to the ruler.

110 See for example Ibn Taghrïbirdī, al-Nujūm al-Zāhirah, vol. 16, p. 357.

111 See for example Ibn Taghrībirdī, al-Manhal al-Sāfì, vol. 3, p. 506; Turkish-period sources usually refer to the process of the mamlük's enslavement and manumission by expressions such as "he remained his mamlük until he was manumitted" (wa-lam yazal fi jumlat mamālīkihi ilà an a'taqahu), see for example al-Nuwayrī, Nihāyat al-Arab, vol. 33, p. 291. 
At least until al-Nāṣir Muhammad b. Qalāwūn's third reign mam$l \bar{u} k \mathrm{~s}$ were not manumitted automatically, and the servile phase of their life was not a mere formality. Until that period many of the mamlüks were war captives, and we may safely assume that their enslavement was a traumatic event. Military slaves were considered property and they lacked a legal identity of their own. They perceived themselves as slaves for lacking family ties. The master's domination over them was total and their manumission is sometimes compared to a release from imprisonment or captivity. They were often manumitted only upon their master's death.

It may be that starting from al-Nāṣir Muhammad b. Qalāwūn's third reign the enslavement of Turkish mamlüks who had been sold by their families became more of a formality or more limited in time. On the other hand, non-Turkish mamlūks, who were generally Christian war captives, were subject to discrimination. They were disdained, manumitted at a later age and prevented from establishing marital ties with the Qalawunids and creating their own families at a young age. They were perceived by their contemporaries as being "more slaves" than the Turkish mamlüks.

Only in the days of Barqūq a norm of automatic manumission emerged, and in the Circassian period the servile phase in the life of a mamlu $k$ became more of a formality and limited in time. The mamlük was perceived more as servant rather than slave. Still, slave status never became a source of pride.

\section{Bibliography}

Aigle, Denise, "The Mongol Invasions of Bilād al-Shām by Ghāzān Khān and Ibn Taymiyah's Three “Anti-Mongol” Fatwas", Mamlūk Studies Review, 11, 2 (2007), pp. 89-120.

Amitai, Reuven, "The Mamlūk Institution, or One Thousand Years of Military Slavery in the Islamic World", in Christopher Brown and Philip D. Morgan (eds.), Arming Slaves: From Classical Times to the Modern Age, New Haven and London, Yale University Press, 2006, pp. 40-78.

Amitai, Reuven, "Military Slavery in the Islamic World: 1000 Years of a SocialMilitary Institution", Lecture Delivered at the University of Trier, Germany, 27 June 2007, pp. 1-12.

Amitai, Reuven, Mongols and Mamluks: The Mamluk-İlkhānid War, 1260-1281, Cambridge, Cambridge University Press, 1995. 
Ayalon, David, L'esclavage du Mamelouk, Jerusalem, Israel Oriental Society, 1951.

Ayalon, David, "The Wafidiya in the Mamluk Kingdom", Islamic Culture, 25 (1951), pp. 89-104.

Al-'Aynī, Badr al-Dīn Maḥmūd, 'Iqd al-Jumān fì Ta'rīkh Ahl al-Zamān, Muhammad Muhammad Amīn (ed.), Cairo, al-Hay’ah al-Mișrīyah al- 'Āmmah li-lKitāb, 1987-1992.

Al-'Aynī, Badr al-Dīn Mạ̣mūd, al-Rawd al-Zāhir fì Sìrat al-Malik al-Ẓāhir Ṭaṭar, Hans Ernst (ed.), Cairo, Dār Ihyyā' al-Kutub al-'Arabīyah, 1962.

Al-'Aynī, Badr al-Dīn Maḥmūd, al-Sayf al-Muhannad fì Sìrat al-Malik alMu'ayyad Shaykh al-Maḥmūdì, Muḥammad Shaltūt (ed.), Cairo, Dār al-Kitāb al-'Arabī li-1-Ṭibā'ah wa-1-Nashr, 1966-1967.

Al-'Aynī, Badr al-Dīn Mạ̣mūd, al-Sulțān Barqūq Mu'assis Dawlat al-Mamālīk al-Jarākisah 1382-1398 Milādī/784-801 Hijrì: min khilāl Makhtūt 'Iqd alJumān fì Ta'rīkh Ahl al-Zamān li-Badr al-Dīn al- Aynī, Imān 'Umar Shukrī (ed.), Cairo, Maktabat Madbūlī, 2002.

Baybars al-Manșūrī, Mukhtār al-Akhbār, 'Abd al-Ḥamīd Șālih Hamdān (ed.), Cairo, al-Dār al-Mișrīyah al-Lubnānīyah, 1993.

Baybars al-Manșūrī, Zubdat al-Fikrah fi Ta'rīkh al-Hijrah, Muhammad 'Ața' Zubaydah (ed.), Cairo, 'Ayn li-l-Dirāsāt wa-l-Buhūth al-Insānīyah wa-1Ijtimāèiyah, 2001.

Beckwith, Christopher, "Aspects of the Early History of the Central Asian Guard Corps in Islam", Archivum Eurasiae Medii Aevi, 4 (1984), pp. 29-43.

Al-Birzālī, al-Qāsim b. Muḥammad b. Yūsuf, Ta'rìkh al-Birzālì, 'Umar 'Abd alSalām Tadmurī (ed.), Beirut, al-Maktabah al-'Așrīyah, 2006.

Broadbridge, Anne F., Kingship and Ideology in the Islamic and Mongol Worlds, Cambridge, Cambridge University Press, 2008.

Cheikho, Louis, Petrus ibn Rahib: Chronicon Orientale, Beirut-Paris-Leipzig, Mațba 'at al-Ābā' al-Yasū'īyīn-Carolus Poussielgue-Otto Harrassowitz, 1903.

Clifford, W.W., "State Formation and the Structure of Politics in Mamluk SyroEgypt, 684-741 A.H./1250-1340 C.E.”, Ph.D. diss., University of Chicago, 1995.

Crone, Patricia, "Mawlā", in P.J. Bearman et al., Encyclopcedia of Islam, 2nd edition, Leiden, E.J. Brill, 1960-2005, vol. 6, pp. 874-882.

Al-Dhahabī, Shams al-Dīn Muhammad, Dhayl Ta'rīkh al-Islām, 'Umar 'Abd alSalām Tadmurī, (ed.), Beirut, Dār al-Kitāb al-'Arabī, 2004.

Al-Dhahabī, Shams al-Dīn Muhammad, Kitāb Duwal al-Islām, Muḥammad Shaltūt (ed.), Egypt, al-Hay’ah al-Mișrīyah al-‘Āmmah li-l-Kitāb, 1974.

Al-Dhahabī, Shams al-Dīn Muḥammad, al-Mukhtār min Ta'rīkh Ibn al-Jazarī, Khuḍayr 'Abbās Muḥammad Khalīfah al-Munshadāwī (ed.), Beirut, Dār alKitāb al-'Arabī, 1988.

Al-Dhahabī, Shams al-Dīn Muhammad, Ta'rīkh al-Islām, 'Umar 'Abd al-Salām Tadmurī (ed.), Beirut, Dār al-Kitāb al-'Arabī, 1987-2004. 
Elbendary, Amina A., "The Sultan, The Tyrant, and The Hero: Changing Medieval Perceptions of al-Zāhir Baybars", Mamlūk Studies Review, 5 (2001), pp. 141-157.

Forand, Paul G., "The Relation of the Slave and the Client to the Master or Patron in Medieval Islam", International Journal of Middle East Studies, 2, 1 (1971), pp. 59-66.

Golden, Peter B., "Khazar Turkic Ghulāms in Caliphal Service”, Journal Asiatique, 291, 1 (2004), pp. 279-309.

Golden, Peter B., "The Terminology of Slavery and Servitude in Medieval Turkic", in David De Weese (ed.), Studies on Central Asia in Honor of Yuri Bregel, Bloomington, Indiana University, 2001, pp. 27-56.

Haarmann, Ulrich, "Arabic in Speech, Turkish in Lineage: Mamlūks and Their Sons in the Intellectual Life of Fourteenth-Century Egypt and Syria", Journal of Semitic Studies, 33, 1 (1988), pp. 81-114.

Haarmann, Ulrich, "Joseph's Law-The Careers and Activities of Mamlūk Descendants before the Ottoman Conquest of Egypt", in Thomas Philipp and Ulrich Haarmann (eds.), The Mamlūks in Egyptian Politics and Society, Cambridge, Cambridge University Press, 1998, pp. 55-84.

Haarmann, Ulrich, "The Sons of Mamlūks as Fief-holders in Late Medieval Egypt", in Tarif Khalidi (ed.), Land Tenure and Social Transformation in the Middle East, Beirut, American University in Beirut, 1984, pp. 141-168.

Herzog, Thomas, "Legitimität durch Erzählung. Ayyūbidische und kalifale Legitimation mamlūkischer Herrschaft in der populären Sìrat Baibars", in Stephan Conermann and Anja Hatam (eds.), Die Mamlūken: Studien zu ihrer Geschichte und Kultur. Zum Gedenken an Ulrich Haarmann (1942-1999), Hamburg, EB-Verlag, 2003, pp. 251-268.

Holt, PM, "Literary Offerings: A Genre of Courtly Literature", in Thomas Philipp and Ulrich Haarmann (eds.), The Mamlüks in Egyptian Politics and Society, Cambridge, Cambridge University Press, 1998, pp. 3-16.

Holt, P.M., "Prediction or Propaganda? The Predestined Sultan in the Mamluk Period", in Rudolf Veselý and Eduard Gombár (eds.), Zafar Nāme: Memorial Volume of Felix Tauer, Prague, Enigma Corporation Ltd., 1996, pp. 133-141.

Ibn 'Abd al-Zāhir, Muhyī al-Dīn 'Abdallāh, al-Rawd al-Zāhir fì Sìrat al-Malik al-Z̄āhir, 'Abd al-'Azīz al-Khuwayțir (ed.), Riyadh, Mu'assasat Fu'ād, 1976.

Ibn Ājā, Shams al-Dīn Muhammad b. Maḥmūd b. Khalīl, Ta'rīkh al-Amīr Yashbak al-Z̄āhirī, 'Abd al-Qādir Aḥmad Ṭulayhat (ed.), Cairo, Dār al-Fikr al-'Arabī, 1973.

Ibn al-Dawādārī, Abū Bakr b. 'Abdallāh b. Aybek, Kanz al-Durar wa-Jāmi' alGhurar, H.R. Roemer (ed.), Cairo, Qism al-Dirāsāt al-Islāmìyah bi-l-Ma'had al-Almānī li-l-Āthār, 1960-1982.

Ibn Duqmāq, Șārim al-Dīn Ibrāhīm b. Muhammad b. Aydamur al- Alā'ī, al-Jawhar al-Thamīn fì Siyar al-Khulafā' wa-l-Mulūk wa-l-Salāțin, Sa īd 'Abd alFattạ̣ 'Āshūr (ed.), Riyadh, Jāmi`at Umm al-Qurá, 1982. 
Ibn Duqmāq, Șārim al-Dīn Ibrāhīm b. Muḥammad b. Aydamur al-'Alā’̄ì, al-Nafhah al-Miskīyah fi-l-Dawlah al-Turkìyah, 'Umar 'Abd al-Salām Tadmurī (ed.), Beirut, al-Maktabah al-'Așriyah, 1999.

Ibn Duqmāq, Șārim al-Dīn Ibrāhīm b. Muhammad b. Aydamur al-'Alā'̄i, Nuzhat al-Anām fì Ta'rīkh al-Islām, Samīr Tabbārah (ed.), Beirut, al-Maktabah al'Așrìyah, 1999.

Ibn al-Furāt, Nāṣir al-Dīn Muhammad b. 'Abd al-Rahīm, Ta'rīkh Ibn al-Furāt, Q. Zurayk (ed.), Beirut, al-Maṭba ah al-Amīrikānīyah, 1939-1942.

Ibn Hajar al-'Asqalānī, Shihāb al-Dīn Aḥmad, Inbā' al-Ghumr bi-Abnā' al- 'Umr fi-l-Ta'rīkh, Hyderabad, Maṭba'at Majlis Dā'irat al-Ma'ārif al-'Uthmānīyah, 1967-1976.

Ibn Hijjjī, Aḥmad b. 'Alā' al-Dīn, Ta’rīkh Ibn Hijjì, Abū Yaḥyā 'Abdallāh al-Kundarī (ed.), Beirut, Dār Ibn Hazm 2003.

Ibn Iyās, Muhammad b. Aḥmad, Badā'i' al-Zuhūr fì Waqā’ i' al-Duhūr, Cairo, Mațābie al-Sha'b, 1960.

Ibn Kathīr, Ismāê̄l b. 'Umar Abū al-Fidā', al-Bidāyah wa-l-Nihāyah fì-l-Ta'rīkh, Beirut, Dār al-Ma‘ārif, 1966.

Ibn al-Mughayzil, Nūr al-Dīn 'Alī b. 'Abd al-Rahīm, Dhayl Mufarrij al-Kurūb fi Akhbār Banī Ayyūb, 'Umar 'Abd al-Salām Tadmurī (ed.), Beirut, al-Maktabah al-'Așrīyah, 2004.

Ibn Qāội Shuhbah, Taqī al-Dīn Abū Bakr b. Aḥmad, Ta'rīkh Ibn Qāḍ̄ Shuhbah, 'Adnān Darwīsh (ed.), Damascus, al-Ma had al-'Ilmī al-Faransī, 1977-1997.

Ibn Șașrā, Muḥammad b. Muḥammad, al-Durrah al-Muḍ̂'ah fì-l-Dawlah al-Z̄āhirìyah, William M. Brinner (ed.), Berkley, University of California, 1963.

Ibn Shaddād, 'Izz al-Dīn Muḥammad b. 'Alī b. Ibrāhīm, Ta'rīkh al-Malik al-Ẓāhir, Aḥmad Huṭayt (ed.), Wiesbaden, Franz Steiner, 1983.

Ibn Taghrībirdī, Yūsuf, Hawādith al-Duhūr fì Madà al-Ayyām wa-l-Shuhūr, Muhammad Kamāl al-Dīn 'Izz al-Dīn (ed.), Beirut, 'Ālam al-Kutub, 1990.

Ibn Taghrībirdī, Yūsuf, Kitāb al-Nujūm al-Zāhirah fì Mulūk Miṣr wa-l-Qāhirah, Cairo, Wizārat al-Thaqāfah wa l-Irshād al-Qawmī, 1963-1972.

Ibn Taghrībirdī, Yūsuf, al-Manhal al-Șāfi wa-l-Mustawfà ba'da al-Wāfì, Muhammad Muhammad Amīn (ed.), Cairo, al-Hay'ah al-Mișrīyah al-`Āmmah li 1-Kitāb, 1984-2006.

Al-Jawharī, ‘Alī b. Dā'ūd, Nuzhat al-Nufūs wa-l-Abdān fì Ahl al-Zamān, Hasan al-Habashī (ed.), Cairo, Maṭa'at Dār al-Kutub, 1970-1994.

Al-Kutubī, Muḥammad b. Shākir, Fawāt al-Wafayāt, Muhammad Muhyī al-Dīn 'Abd al-Hamīd (ed.), Cairo, Maktabat al-Nahḍah al-Mișriyah, 1951.

Al-Kutubī, Muhammad b. Shākir, 'Uyūn al-Tawārìkh, 'Abd al-Mun 'im Nabīlah (ed.), Baghdad, Maṭba'at As'ad, 1991.

Irwin, Robert, "Factions in Medieval Egypt", Journal of the Royal Asiatic Society, (1986), pp. 228-246.

Levanoni, Amalia, "Awlad al-Nas in the Mamluk Army during the Bahri Period", 
in Ami Ayalon and David Wasserstein (eds.), Mamluks and Ottomans: Studies in Honour of Michael Winter, London-New York, Routledge, 2006, pp. 96-105. Little, Donald P., "Notes on Aitamiš, a Mongol Mamlūk", in Ulrich Haarmann and Peter Bachmann (eds.), Die islamische Welt zwischen Mittelalter und Neuzeit: Festschrift für Hans Robert Roemer zum 65. Geburtstag, BeirutWiesbaden, Orient-Institut der Deutschen Morganlandischen GesellschaftFranz Steiner, 1979, pp. 387-401.

Al-Makīn, Jirjis Ibn al-'Amīd, Akhbār al-Ayyūbìȳ̄n, Port Said, Maktabat alThaqāfah al-Dīniyah, no date.

Al-Malatī, 'Abd al-Bāsiṭ b. Khalīl b. Shāhīn, Nayl al-Amal fi Dhayl al-Duwal, 'Umar 'Abd al-Salām Tadmurī (ed.), Beirut and Șaydā, al-Maktabah al-'Așrīyah, 2002. Al-Maqrīzī, Taqī al-Dīn Aḥmad b. 'Alī, Kitāb al-Sulūk li-Ma'rifat Duwal alMulūk, Muḥammad Muṣtafā Ziyādah and Sa ${ }^{1} \overline{1} d$ 'Abd al-Fattạ̣ 'Āshūr (eds.), Cairo, Dār al-Kutub al-Mișrīyah, 1934-1973.

Marmon, Shaun E., "Domestic Slavery in the Mamluk Empire: A Preliminary Sketch", in Shaun E. Marmon (ed.), Slavery in the Islamic Middle East, Princeton, Markus Wiener Publishers, 1999, pp. 1-23.

Mottahedeh, Roy P., Loyalty and Leadership in an Early Islamic Society, Princeton, Princeton University Press, 1980.

Mufaḍ̣al b. Abī al-Faḍā'il, al-Nahj al-Sadìd wa-l-Durr al-Farìd fìmā ba'da Ta'rīkh Ibn al-'Amìd, Samira Kortantamer (ed.), Freiburg im Breisgau, Klaus Schwarz Verlag, 1973.

Northrup, Linda S., "The Bahrīi Mamlūk Sultanate, 1250-1390”, in Carl F. Petry (ed.), The Cambridge History of Egypt. Vol. 1: Islamic Egypt, 640-1517, Cambridge, Cambridge University Press, 1998, pp. 242-289.

Al-Nuwayrī, Shihāb al-Dīn Aḥmad, Nihāyat al-Arab fì Funūn al-Adab, Cairo, alMu'assasah al-Mișrìyah al-‘Āmmah li-1-Ta'lïf wa-l-Nashr, 1964-1997.

Al-Nuwayrī al-Iskandarānī, Muḥammad b. Qāsim b. Muhammad, Kitāb al-Ilmām bi-l-I'lām fimā jarat bihi al-Ahkām wa-l-Umūr al-Maqdìyah fì Waq at alIskandarīyah, Etienne Combe and Aziz Suryal Atiya (eds.), Haiderabad, Dā'irat al-Ma'ārif al-'Uthmānìyah, 1968-1976.

Patterson, Orlando, Slavery and Social Death, Massachusetts-London, Harvard University Press, 1982.

Pipes, Daniel, "Mawlas: Freed Slaves and Converts in Early Islam", in John Ralph Willis (ed.), Slaves and Slavery in Africa: Volume One: Islam and the Ideology of Enslavement, London-New York, Routledge, 1986, pp. 199-248.

Al-Qalqashandī, Abū al- 'Abbās Ahmmad b. 'Alī, Subh al-A 'shà fì Sinā'at al-Inshā', Muhammad Qindīl al-Baqlì (ed.), Cairo, Wizārat al-Thaqāfah wa-l-Irshād alQawmī, 1964.

Qarațāy al-'Izzī al-Khāzindārī, Ta'rīkh Majmū' al-Nawādir mimmā jarà li-l-Awā'il wa-l-Awākhir, Horst Hein and Muhammad al-Hujayrī (eds.), Beirut, alMa had al-Almānī li-l-Abhāth al-Sharqīyah, 2005. 
Rabbat, Nasser O., "The Changing Concept of Mamlūk in the Mamluk Sultanate in Egypt and Syria", in Miura Toru and John Edward Philips (eds.), Slave Elites in the Middle East and Africa: A Comparative Study, London-New York, Kegan Paul International, 2000, pp. 81-98.

Rabīi, Hasanayn Muhammad, "The Training of the Mamlūk Fāris", in V.J. Parry and Malcolm E. Yapp (eds.), War, Technology and Society in the Middle East, London, Oxford University Press, 1975, pp. 153-163.

Richards, D.S., "Mamlūk Amirs and Their Families and Households", in Thomas Philipp and Ulrich Haarmann (eds.), The Mamlūks in Egyptian Politics and Society, Cambridge, Cambridge University Press, 1998, pp. 32-54.

Al-Șafadī, Șalāḥ al-Dīn Khalīl b. Aybek, A'yān al-'Aṣr wa-A'wān al-Naṣr, 'Alī Abū Zayd (ed.), Beirut, Dār al-Fikr al-Mưāṣir, 1998.

Al-Ṣafadī, Șalāḥ al-Dīn Khalīl b. Aybek, al-Wāfì bi-l-Wafayāt, Wiesbaden, Franz Steiner, 1962-2004.

Al-Sakhāwī, Shams al-Dīn Muḥammad b. 'Abd al-Raḥmān, al-Ḍaw' al-lāmi` liAhl al-Qarn al-Tāsi', Cairo, Dār al-Kitāb al-Islamī, no date.

Al-Sakhāwī, Shams al-Dīn Muḥammad b. 'Abd al-Raḥmān, Wajīz al-Kalām fìl-Dhayl 'alà Duwal al-Islām, Beirut, Mu'assasat al-Risālah, 1995.

Shāfi' b. 'Alī, al-Faḍl al-Ma'thūr min Sìrat al-Sulțān al-Malik al-Manșūr, 'Umar 'Abd al-Salām Tadmurī (ed.), Beirut, al-Maktabah al-'Așrīyah, 1998.

Shoshan, Boaz, Popular Culture in Medieval Cairo, Cambridge, Cambridge University Press, 1993.

Al-Shujā'ī, Shams al-Dīn, Ta'rīkh al-Malik al-Nāṣir Muhammad ibn Qalāwūn al-Șālih̄i wa-Awlādihi, Barbara Schäfer (ed.), Wiesbaden, Franz Steiner Verlag, 1977, Erster Teil (Arabischer Text).

Stewart, Angus, "Between Baybars and Qalāwūn: Under-age Rulers and Succession in the Early Mamlūk Sultanate", Al-Masāq, 19, 1 (2007), pp. 47-54.

Thorau, Peter, The Lion of Egypt: Sultan Baybars I and the Near East in the Thirteenth Century, P.M. Holt (trans1.), London-New York, Longman, 1992.

Al- 'Umarī, Ibn Faḍlallāh Shihāb al-Dīn Aḥmad b. Yaḥyā, Kitāb Masālik al-Abṣār wa-Mamālik al-Amṣār: Mamālik Bayt Jinkiz Khān, Klaus Lech (ed.), Wiezbaden, O. Harrassowitz, 1968.

Van Steenbergen, Jo, Order out of Chaos. Patronage, Conflict and Mamluk SocioPolitical Culture. 1341-1382, Leiden, Brill, 2006.

Yosef, Koby, "Dawlat al-Atrāk or Dawlat al-Mamālīk? Ethnic Origin or Slave Origin as the Defining Characteristic of the Ruling Elite in the Mamluk Sultanate", Jerusalem Studies in Arabic and Islam, 39 (2012), pp. 387-410.

Yosef, Koby, "Ethnic Groups, Social Relationships and Dynasty in the Mamluk Sultanate (1250-1517)", Ph.D. diss., University of Tel-Aviv, 2011 (Hebrew).

Yosef, Koby, "Mamluks and Their Relatives in the Period of the Mamluk Sultanate (1250-1517)", Mamlūk Studies Review, 16 (2012), pp. 55-69.

Yosef, Koby, "The Names of the Mamlūks - Ethnic Groups and Ethnic Solidarity 
in the Mamlūk Sultanate (1250-1517)", in Amalia Levanoni (ed.), Egypt and Syria under Mamlūk Rule: Political, Social and Cultural Aspects (forthcoming).

Al-Yūnīnī, Quṭb al-Dīn Mūsā b. Muhammad b. Aḥmad, Dhayl Mir'āt al-Zamān, Hyderabad, Majlis Dā'irat al-Ma'ārif, 1954-1961.

Al-Yūsufī, Mūsá b. Muhammad b. Yahyāā, Nuzhat al-Nāzir fì Sìrat al-Malik alNāṣir, Ahmmad Huṭayt (ed.), Beirut, 'Ālam al-Kutub, 1986.

Ze'evi, Dror, "My Slave, My Son, My Lord: Slavery, Family and State in the Islamic Middle East", in Miura Toru and John Edward Philips (eds.), Slave Elites in the Middle East and Africa: A Comparative Study, London-New York, Kegan Paul International, 2000, pp. 71-80.

Zetterstéen, Karl Vilhelm, Beiträge zur Geschichte der Mamlūkensultane in den Jahren 690-741 der Higra nach arabischen Handschriften, Leiden, Brill, 1919.

Recibido: 21/12/2011

Aceptado: 07/05/2012 